\title{
ANALISIS OPERASIONAL TERMINAL PETI KEMAS DALAM MENUNJANG KELANCARAN BONGKAR MUAT PADA PT. PELABUHAN INDONESIA II CABANG PANJANG
}

\author{
Oleh: \\ Melan Susanty Purnamasari ${ }^{1}$ \\ Rio Donnytal ${ }^{2}$ \\ Program Studi Administrasi Bisnis FISIP Universitas Tulang Bawang Lampung \\ e-Mail: melan.susanty@utb.ac.id
}

\begin{abstract}
ABSTRAK
Penelitian ini bertujuan bagi Terminal Peti Kemas Panjang yang dapat dimanfaatkan dalam memberikan masukan untuk memperkecil tingkat angka ketidaklancaran di operasonal. Dengan meningkatnya kualitas yang menunjang kelancaran bongkar muat pada PT. Pelabuhan Indonesia II Cabang Panjang, sehingga dapat mempengaruhi tingkat kepercayaan pada pemilik barang yang menggunakan jasa bongkar muat barang dan dapat menambah keuntungan bagi sektor jasa bongkar muat khususnya pada PT. Pelabuhan Indonesia II Cabang Panjang. Metode penelitian ini menggunakan metode deskriptif kuantitatif. Tempat penelitian pada PT. Pelabuhan Indonesia II Cabang Panjang. Sampel penelitian adalah karyawan yaitu sebanyak 11 orang karyawan. Teknik analisis data menggunakan tabel dan grafik distirbusi frekuensi. Sedangkan uji hipotesis menggunakan uji t. Hasil penelitian disimpulkan operasional Terminal Peti Kemas sangat menunjang kelancaran bongkar muat siswa, semakin baik opersional maka semakin menunjang kelancaran bongkar muat. Tingginya pengaruh operasional Terminal Peti Kemas dalam menunjang kelancaran bongkar muat adalah sebesar $72,4 \%$. Hubungan antara operasional Terminal Peti Kemas sangat menunjang kelancaran bongkar muat adalah sangat kuat $(r=0,851)$, karena nilai ini koefisien korelasi tersebut berada pada interval koefisien 0,8 - 1,0 dan termasuk tingkat hubungan yang sangat kuat.
\end{abstract}

Kata kunci: analisis, operasional, peti kemas, bongkar muat, pelabuhan

\section{PENDAHULUAN}

Sehubungan dengan pemberlakuan zona perdagangan beba dikawasan Asean AFTA (Asean Free Trade Area) tahun 2003 tingkat perdagangan luar negeri, Indonesia dapat meningkat dengan pesat. Dengan keadaan yang meningkat tersebut membuat pentingnya pelayanan akan bongkar muat kapal untuk dilaksanakan dikerenakan sebagai modal dalam persaingan dengan negeri tetangga lainnnya didalam ruang lingkup Asean maupun negara-negara internasional lainnya. Pelabuhan pun memiliki salah satu fasilItas antara lan yaitu Terminal Peti Kemas yang mana digunakan sebagai tempat melakukan kegiatan membongkar dan memuat peti kemas dari atas kapal ke dermaga atau sebaliknya. Teminal Peti kemas untuk menjalankan 
aktivitas bongkar muat yang dilengkapi dengan alat-alat dengan berkapasitas lebih kurang dari 50 ton dikarenakan beragamnya jumlah tonase pada saat pengiriman peti kemas dari pelabuhan luar negeri maupun dari Indonesia sendiri. Kegemaran pun muncul untuk melakukan pengguanaan container di seluruh dunia dalam bentuk pengiriman barang dengan jumlah yang sangat banyak, hal ini dikerenakan beberapa faktor antara lain :

1. Cepat dan ekonomis dalam menangani peti kemas, terutama dalam membongkar dan memuat peti kemas dipelabuhan.

2. Keamanan terhadap kerusakan dan pencurian lebih terjaga, terutama untuk barang-barang kecil atau berharga

3. Pembungkus barang tidak perlu terlalu kuat dikarenakan tumpukan dapat dibatas setinggi dalamnya peti kemas.

4. Penditribusiannya dapat berjalan dengan efektif dan efisien.

Dengan maraknya penggunaan container, Terminal Peti Kemas pun akan melakukan penanganan yang baik dalam implementasinya dilapangan, dimana hal tersebut dilakukan untuk menekan biaya yang dikeluarkan baik dari perusahaan pelayaran maupun dari perusahaan Terminal Peti Kemas khususnya PT. Pelabuhan Indonesia II Cabang Panjang. Sebelum melakukan bongkar muat container Terminal Peti Kemas Panjang juga akan merencanakan atau memperkirakan sesuatu yang akan digunakan dengan mengusahakan penggunaannya seperti contoh memperkirakan penggunaan jumlah alat $\mathrm{CC}$ ( containerCrane) RTG ( Rubber Tired Yard Gantry Crane ), Head Truck, Penggerak aalat CC, forklift, Slide Loader dan lain-lainnya.
Dari hasil rencana kegiatan bongkar muat kapal yang telah dibuat, terkadang pada saat pelaksanaan dilapangan tersebut mengalami suatu gangguan atau kendala-kendala yang caranya menghambat dalam kelancaran operasional bongkar muat. Hal tersebut akan berdampak sangat buruk bagi pelayaran antara lain yaitu biaya operasional yang menjadi tinggi, rusaknya kapal yang lainnya dan juga citra nama pelabuhan pun akan tidak baik dimata pelabuhan dunia.

Berdasarkan uraian yang telah dikemukanan pada latar belakang, adapun identifikasi masalah yang timbul pada proses kegiatan bongkar muat kapal antara lain :

1. Stabilitas kapal yang tidak baik

2. Kerusakan alat

3. Force majeur

4. Kegiatan Shiffhing dil apangan

Di dalam masalah kegiatan bongkar muat ini terdapat faktor-faktor yang menghambat dalam aktifitas operasional yang tidak lancar. Oleh karena itu penulis hanya membatasi pada analisa operasional Terminal Peti Kemas dalam menunjang kelancaran bongkar muat pada PT. Pelabuhan Indonesia II cabang Panjang

Tujuan Penelitian adalah bagi Terminal Peti Kemas Panjang yang dapat dimanfaatkan dalam memberikan masukan untuk memperkecil tingkat angka ketidaklancaran di operasonal. Hipotesis dalam penelitian ini adalah "Apabila operasional Terminal Peti Kemas berjalan optimal maka akan ada pengaruh posistif dan signifikan dalam menunjang kelancaran bongkar muat barang “.

\section{TINJAUAN PUSTAKA}

Menurut Sugiyono (2015) analisis adalah kegiatan untuk mencari pola, atau cara berpikir yang berkaitan dengan pengujian 
secara sistematis terhadap sesuatu untuk menentukan bagian, hubungan antar bagian, serta hubungannya dengan keseluruhan. Menurut Satori dan Komariyah (2014), definisi analisis adalah usaha untuk mengurai suatu masalah menjadi bagianbagian sehingga, susunan tersebut tampak jelas dan kemudian bisa ditangkap maknanya atau dimengerti duduk perkaranya.

Pengertian operasional menurut Husein Umar (2007) adalah penentuan suatu konstruk sehingga menjadi variabel maupun variabel-variabel yang dapat diukur. Menurut Asep Hermawan (2005), pengertian operasional adalah penjelasan bagaimana kita dapat mengukur variabel. Pengukuran tersebut dapat dilakukan dengan angka-angka maupun atribut-atribut tertentu.

Pengertian Pelabuhan adalah tempat yang terdiri dari daratan dan perairan di sekitarnya dengan batas-batas tertentu sebagai tempat kegiatan pemerintahan dan kegiatan ekonomi yang dipergunakan sebagai tempat kapal bersandar, berlabuh, naik turunnya penumpang dan bongkar muat kapal yang dilengkapi dengan fasilitas keselamatan pelayaran serat sebagai tempat perpindahan inter dan antar model transportasi (Suyono, R.P., 2005). Adapun yang ada pelabuhan berupa fasilitas pelabuhan adalah untuk menunjang aktivitas di pelabuhan terdapat berbagai fasilitas, kelengkapan fasilitas ini juga bisa menjadi ukuran baik buruknya suatu pelabuhan.

Peti kemas adalah suatu kemasan yang dirancang secara khusus dengan ukuran tertentu, dapat dipakai berulang kali dan dipergunakan untuk menyimpan sekaligus mengangut muatan yang ada di dalamnya. (Wahyu Agung Prihartanto, 2014)
Pengertian Pengawasan menurut pendapat Sondang P. Siagian (2005) menyatakan bahwa pengawasan adalan proses pengamatan dari pada pelaksanaan seluruh kegiatan organisasi untuk menjamin agar supaya pekerjaan yang sedang dilaksanakan berjalan sesuai dengan rencana yang telah ditentukan sebelumnya. Dari pendapat tersebut diketahui bahwa terdapat hubungan yang erat antara perencanaan dan pengawasan. Tanpa rencana pengawasan tidk mungkin dilaksanakan. Tujuan dari pengawasan tidak lain adalah untuk mencapai hasil atau proses suatu pelaksanaan pekerjaan secara berdya guna (efisien) dan begasil guna (efektif) sesuai dengan rencana yang telah ditentukan sebelumnya. Menurut pendapat Arifin Abdul Rachman (2001) tujuan pengawasan adalah untuk membuat segenap kegiatankegiatan manajemen dinamis dan berhasil guna secara efektif dan efisien.

\section{METODOLOGI PENELITIAN}

Pelabuhan Panjang yang berada di Provinsi Lampung, pada mulanya hanyalah Pelabuhan kecil di Teluk Betung yang disinggahi kapal-kapal motor dan perahu layar yang mengangkut hasil perikanan dan pertanian keluar daerah, dan sebaliknya mengangkut barang-barang dari luar daerah untuk memenuhi kebutuhan Provinsi Lampung.

Pelabuhan alam yang cukup ideal sebab sebagian luar kolam Pelabuhan terdapat satu gugus karang sepanjang 1500 meter yang secara tidak langsung merupakan panahan gelombang, kedalam kolam mencapai 14 LWS dan lebar pintu kolam 1500 meter yang memungkinkan kapalkapal berukuran 10 ribu ton atau lebih dapat masuk dan berlabuh dengan aman.

Sejalan dengan adanya peningkatan kegiatan, maka pada abad XVII oleh Pemerintah Hindia Belanda dibangun 
Pelabuhan Panjang yang lokasinya kurang lebih $3 \mathrm{Km}$ dari pelabuhan lama yang dikenal dengan nama Oasthaven. Pembangunan tahap pertama yaitu dermaga sepanjang 200 meter dengan menggunakan ontruks Caison dengan kedalaman -7 LWS beserta 1 ( satu ) unit gudang dengan luas kurang lebih 1.000. m persegi. Adapun pengolahan pelabuhan Umum di Indonesia sejak tahun 1960 dilakukan oleh Badan Usaha Milik Negara diberikan wewenang untuk mengelola pelabuhan umum sejak tahun 1960 sampai 1993 telah mengalami perubahan yang disesuaikan dengan arah kebijakan mengimbangi pertumbuhan permintaan pelayanan jasa pelabuhn yang dinamis.

Adapun penelitian ini menggunakan metode kuantitatif, dimana merupakan metode analisis yang dilakukan terhadap data yang diperoleh dari hasil jawaban kuesioner yang digunakan untuk menganalisis data yang berbentuk angkaangka, Arikunto (2002).

Untuk memperoleh data yang dibutuhkan sebagai penunjang dalam penulisan proposal penelitian ini, maka instrumen tekhnik pengumpulan data dilakukan sebagai berikut :

\section{Angket Kuesioner}

Angket atau kuesioner adalah sejumlah pertanyaan tertulis yang digunakan untuk memperoleh informasi dari responden dalam arti laporan tentang pribadinya atau hal hal yang ia ketahui. Arikunto (2006). Dalam hal ini kuesioner disebar kepada responden yakni 11 orang Staf pada bagian bongkar muat PT. Pelabuhan Indonesia II Cabang Panjang.

2. Dokumentasi

Catatan tertulis tentang berbagai kegiatan atau masa lalu. Semua dokumen yang berhubungan dengan penelitian perlu di catat sebagai sumber informasi.
Sugiyono (2005) menyatakan bahwa populasi adalah wilayah generalisasi yang terdiri atas objek/subjek yang mempunyai kuantitas dan karakteristik tertentu yang ditetapkan oleh peneliti untuk dipelajari dan kemudian ditarik kesimpulannya. Furchan (2004) menyatakan bahwa populasi merupakan semua anggota kelompok orang, kejadian, atau objek yang telah dirumuskan secara jelas. Nazir (2005: 271) menyatakan bahwa populasi adalah kumpulan dari individu dengan kualitas serta ciri-ciri yang telah ditetapkan. Jadi, intinya populasi adalah keseluruhan dari objek yang akan diteliti. Populasi dalam penelitian ini adalah berjumlah 11 orang karyawan.

Sampel adalah bagian dari sebuah populasi yang dianggap dapatmewakili dari populasi tersebut. Untuk menentukan besarny sampel apabila subjek kurang dari 100, lebih baik diambil semua sehingga penelitiannya penelitian populasi. Jika subjeknya lebih besar dapat diambil antara 10-15 \% atau 20-25 \%. Dalam penelitian inidigunakan sampel sampel dari semua populasi berdasarkan jumlah responden yang ada kurang dari 100 orang. Jadi sampel dalam penelitian ini adalah berjumlah I1 orang. Dengan demikian penelitian ini menjadi penelitian populasi.

\section{Analisis Data Kuantitatif}

Metode analisis ini merupakan metode analisis yang dilakukan terhadap data yang diperoleh dari hasil jawaban kuesioner menganalisis data yang berbentuk angkaangka.

Uji validitas instrumen dmenggunakan korelasi Product Moment dengan rumus sebagai berikut:

$$
r x y=\frac{\sum X Y-\frac{(\Sigma X)\left(\sum Y\right)}{N}}{\sqrt{\left\{\sum X^{2}-\frac{(\Sigma X)^{2}}{N}\right\}\left\{\sum Y^{2}-\frac{(\Sigma Y)^{2}}{N}\right\}}}
$$


Keterangan :

$\mathrm{r}_{x \gamma} \quad=$ Koefisien korelasi

$\sum X \quad=$ Jumlah skor item

$\sum Y \quad=$ Jumlah skor total

$N \quad=$ Jumlah sampel

(Arikunto, 2002)

Selanjutnya untuk mengetahui validitas setiap butir item, teknik analisis dilanjutkan dengan uji t dengan rumus sebagai berikut :

thitung $=\frac{r \sqrt{n-2}}{r \sqrt{1-r^{2}}}$

Keterangan :

thitung $=$ nilai uji $\mathrm{t}$

$\mathrm{r}=$ Koefisien kolerasi product moment

$\mathrm{n}=$ Jumlah sampel uji coba

Kriteria uji validitas berdasarkan uji t tersebut diatas adalah

1. Jika thitung $>t_{\text {tabel }}(\alpha 0,05, d b=n-1)$, maka butir item adalah valid

2. Jika thitung $<t_{\text {tabel }}(\alpha 0,05, d b=n-1)$, maka butir item adalah tidak valid

(Sugiyono, 2015)

\section{HASIL DAN PEMBAHASAN}

\section{Analisis Operasional Terminal Peti $\operatorname{Kemas}(\mathbf{X})$}

1. Pembongkaran Peti kemas tepat waktu Hasil penelitian tentang pembongkaran Peti kemas tepat waktu dapat dilihat pada Tabel 4.1 dibawah ini.

Tabel 4.1 Pembongkaran Peti kemas tepat waktu.

\begin{tabular}{|l|r|r|}
\hline Jawaban & Jumlah & \multicolumn{1}{l|}{$\%$} \\
\hline Ya & 7 & 63,64 \\
\hline Kadang-kadang & 4 & 36,36 \\
\hline Tidak & 0 & 0,00 \\
\hline Jumlah & 11 & 100 \\
\hline
\end{tabular}

Berdasarkan Tabel 4.1 di atas diperoleh sebanyak 7 orang pegawai $(63,64 \%)$ selalu tepat waktu dalam proses pembongkaran Peti kemas, 4 orang pegawai $(36,36 \%)$. Hal ini menunjukkan sebagian besar pegawai memiliki disiplin yang baik dalam hal kehadiran.

2. Melaksanakan sidik jari kehadiran.

Pegawai yang memiliki disiplin adalah selalu melaksanakan sidik jari hasil penelitian dapat dilihat pada Tabel 4.2 dibawah ini.

Tabel 4.2 Melaksanakan sidik jari kehadiran.

\begin{tabular}{|l|r|r|}
\hline Jawaban & Jumlah & \multicolumn{1}{l|}{$\%$} \\
\hline Ya & 11 & 100,00 \\
\hline Kadang-kadang & 0 & 0,00 \\
\hline Tidak & 0 & 0,00 \\
\hline Jumlah & 11 & 100 \\
\hline
\end{tabular}

Pada Tabel 4.2 di atas menunjukkan seluruh pegawai $(100 \%)$ selalu melaksanakan sidik jari kehadiran. Hal ini berarti pegawai sangat disiplin dalam mengisi daftar hadir.

3. Mengatur proses bongkar muat Peti kemas.

Hasil tentang kegiatan pegawai dilihat pada Tabel 4.3 dibawah ini.

Tabel 4.3 Mengatur proses bongkar muat Peti kemas.

\begin{tabular}{|l|r|r|}
\hline Jawaban & Jumlah & \multicolumn{1}{l|}{$\%$} \\
\hline Ya & 9 & 81,82 \\
\hline Kadang-kadang & 2 & 18,18 \\
\hline Tidak & 0 & 0,00 \\
\hline Jumlah & 11 & 100 \\
\hline
\end{tabular}

Pada Tabel 4.3 terlihat bahwa sebanyak 9 orang pegawai $(81,82 \%)$ selalu mengatur proses bongkar muat peti kemas, 2 orang pegawai $\quad(18,18 \%) \quad$ kadang-kadang mengatur, dan tidak satupun pegawai yang tidak mengatur proses bongkar muat Peti kemas.

4. Menginfentaris kedatangan barang

Hasil penelitian tentang aktivitas menginfentaris kedatangan barang dapat dilihat pada Tabel 4.4 dibawah in. 
Tabel 4.4 Menginfentaris kedatangan barang

\begin{tabular}{|l|r|r|}
\hline Jawaban & Jumlah & \multicolumn{1}{l|}{} \\
\hline Ya & 11 & 100,00 \\
\hline Kadang-kadang & 0 & 0,00 \\
\hline Tidak & 0 & 0,00 \\
\hline Jumlah & 11 & 100 \\
\hline
\end{tabular}

Tabel 4.4 Menunjukkan bahwa semua pegawai (100\%) selalu menginfentaris setiap kedatangan barang. Hal ini berarti semua pegawai selalu menginfentaris kedatangan barang Sehingga operasional bisa berjalan dengan baik.

5. Melakukan pelaksanaan pembongkaran tepat waktu.

Hasil penelitian dibawah ini.

Tabel 4.5 Melakukan pelaksanaan pembongkaran tepat waktu

\begin{tabular}{|l|r|r|}
\hline Jawaban & Jumlah & \multicolumn{1}{l|}{$\%$} \\
\hline Ya & 6 & 54,55 \\
\hline Kadang-kadang & 5 & 45,45 \\
\hline Tidak & 0 & 0,00 \\
\hline Jumlah & 11 & 100 \\
\hline
\end{tabular}

Pada Tabel 4.5 terlihat bahwa sebanyak 6 orang karyawan $(54,55 \%)$ selalu melaksanakan pembongkaran tepat waktu, 5 orang karyawan $(45,45 \%)$ kadang-kadang melaksanakan pembongkaran tepat waktu, dan tidak satupun karyawan yang tidak melakukan pembongkaran tepat waktu.

6. Menerima klaim dari perusahaan pengguna jasa.

Hasil penelitian dapat dilihat pada Tabel 4.6 dibawah ini.

Tabel 4.6 Menerima klaim dari perusak pengguna jasa.

\begin{tabular}{|l|r|r|}
\hline Jawaban & Jumlah & \multicolumn{1}{l|}{} \\
\hline Ya & 0 & 0,00 \\
\hline Kadang-kadang & 3 & 27,27 \\
\hline Tidak & 8 & 72,73 \\
\hline
\end{tabular}

\begin{tabular}{|l|r|r|}
\hline Jumlah & 11 & 100 \\
\hline
\end{tabular}

Tabel 4.6 terlihat bahwa tidak terdapat klaim dari perusahaan pemakai jasa dan 3 orang karyawan $(27,27 \%)$ yang kadangkadang mendapat klaim. Sedangkan 8 $(72,73 \%)$ tidak pernah mendapatkan klaim.

7. Pelaksanaan tugas yang diberikan perusahaan sudah sesuai dengan jumlah operator yang ada.

Hasil penelitian dalam hal tersebut dapat dilihat pada tabel:

\begin{tabular}{|l|r|r|}
\hline Jawaban & Jumlah & \multicolumn{1}{l|}{$\%$} \\
\hline Ya & 6 & 54,55 \\
\hline Kadang-kadang & 4 & 36,36 \\
\hline Tidak & 1 & 9,09 \\
\hline Jumlah & 11 & 100 \\
\hline
\end{tabular}

Dari Tabel 4.7 diperoleh sebanyak 6 orang karyawan $(54,55 \%)$ telah sesuai, 4 orang karyawan $(36,36 \%)$ kadang-kadang sesuai, dan 1 orang karyawan $(9,09 \%)$ tidak sesuai dengan tugas dan fungsinya.

8. Tunjangan yang diberikan kepada karyawan telah sesuai.

Hasil penelitian dapat dilihat pada Tabel 4.8 dibawah ini.

Tabel 4.8 Tunjangan yang diberikan kepada karyawan telah sesuai.

\begin{tabular}{|l|r|r|}
\hline Jawaban & Jumlah & \multicolumn{1}{l|}{$\%$} \\
\hline Ya & 6 & 54,55 \\
\hline Kadang-kadang & 4 & 36,36 \\
\hline Tidak & 1 & 9,09 \\
\hline Jumlah & 11 & 100 \\
\hline
\end{tabular}

sebanyak 6 orang karyawan $(54,55 \%)$ ya telah sesuai, 4 orang karyawan $(36,36 \%)$ kadang-kadang sesuai, dan lorang karyawan $(9,09 \%)$ tidak sesuai.

9. Penyelesaiana tugas dengan cepat dan tepat.

Hasil penelitian dapat dilihat pada Tabel 4.9 dibawah ini. 


\begin{tabular}{|l|r|r|}
\hline Jawaban & Jumlah & \multicolumn{1}{l|}{$\%$} \\
\hline Ya & 6 & 54,55 \\
\hline Kadang-kadang & 5 & 45,45 \\
\hline Tidak & 0 & 0,00 \\
\hline Jumlah & 11 & 100 \\
\hline
\end{tabular}

Pada Tabel 4.9 terlihat bahwa sebanyak 6 orang karyawan $(54,55 \%)$ melaksanakan tugas dengan cepat dan tepat, 5 orang karyawan $\quad(45,54 \%) \quad$ kadang-kadang melaksanakan tugas dengan tepat dan cepat, dan tidak ada yang tidak melaksanakan tugas dengan tepat dan cepat.

10. Jumlah peralatan yang dibutuhkan telah sesuai.

Hasil penelitian tersaji pada Tabel 4.10 dibawah ini.

\begin{tabular}{|l|r|r|}
\hline Jawaban & Jumlah & \multicolumn{1}{l|}{} \\
\hline Ya & 8 & 72,73 \\
\hline Kadang-kadang & 3 & 27,27 \\
\hline Tidak & 0 & 0,00 \\
\hline Jumlah & 11 & 100 \\
\hline
\end{tabular}

Pada Tabel 4.10 menunjukkan bahwa sebanyak 8 orang karyawan $(72,73 \%)$ menjawab ya bahwa peralatan telah sesuai, 3 orang karyawan $(27,27 \%)$ kadang-kadang Jumlah peralatan telah sesuai, dan tidak ada karyawan yang tidak mendapat peralatan yang sesuai.

\section{Kelancaran Bongkar Muat (Y)}

1. Pendidikan telah sesuai dengan tugas yang dibebankan.

Gambaran dilihat pada Tabel 4.11 dibawah ini .

\begin{tabular}{|l|r|r|}
\hline Jawaban & Jumlah & \multicolumn{1}{l|}{} \\
\hline Ya & 9 & 81,82 \\
\hline Kadang-kadang & 2 & 18,18 \\
\hline Tidak & 0 & 0,00 \\
\hline Jumlah & 11 & 100 \\
\hline
\end{tabular}

Pada Tabel 4.11. Pendidikan telah sesuai dengan tugas yang dibebankan Hal ini ditunjukkan oleh sebanyak 9 orang karyawam $(81,82 \%) \quad$ menyatakan pendidikan telah sesuai, dan hanya 2 karyawan $(18,18 \%)$ yang menyatakan kadang-kadang, bahkan tidak satupun yang menyatakan tidak memiliki pendidikan yang susuai dengan tugas

2. Melakukan komunikasi terhadap pengguna jasa.

Gambaran dilihat pada Tabel 4.12 dibawah ini.

\begin{tabular}{|l|r|r|}
\hline Jawaban & Jumlah & \multicolumn{1}{l|}{} \\
\hline Ya & 6 & 54,55 \\
\hline Kadang-kadang & 4 & 36,36 \\
\hline Tidak & 1 & 9,09 \\
\hline Jumlah & 11 & 100 \\
\hline Pada Tabel 4.12 & diperoleh 6 orang \\
\hline
\end{tabular}
karyawan $(54,55 \%)$ menyatakan melakukan komunikasi terhadap pengguna jasa, 4 orang karyawan $(36,36 \%)$ menyatakan kadang-kadang, dan 1 orang karyawan $(9,09 \%)$ menyatakan melakukan komunikasi terhadap pengguna jasa .

3. Pelatihan dalam menjalankan tugas Hasil penelitian dapat dilihat pada Tabel 4.13 dibawah ini.

\begin{tabular}{|l|r|r|}
\hline Jawaban & Jumlah & \multicolumn{1}{l|}{} \\
\hline Ya & 7 & 63,64 \\
\hline Kadang-kadang & 4 & 36,36 \\
\hline Tidak & 0 & 0,00 \\
\hline Jumlah & 11 & 100 \\
\hline
\end{tabular}

Jika mengacu pada Tabel 4.13 di atas, maka terlihat dari sebanyak 7 orang karyawan $(63,64 \%)$ yang menyatakan mendapat pelatihan dalam menjalankan tugas, dan kadang-kadang mendapatkan pelatihan 4 orang karyawan $(36,36 \%)$.

4. Melakukan komunikaasi dengan pengguna jasa

Hasil penelitiannya adalah dapat dilihat pada Tabel 4.14 dibawah ini. 


\begin{tabular}{|l|r|r|}
\hline Jawaban & Jumlah & \multicolumn{1}{l|}{} \\
\hline Ya & 7 & 63,64 \\
\hline Kadang-kadang & 3 & 27,27 \\
\hline Tidak & 1 & 9,09 \\
\hline Jumlah & 11 & 100 \\
\hline
\end{tabular}

Berdasarkan Tabel 4.14, Dari 7 orang karyawan $(63,64 \%)$ menyatakan melakukan komunikasi terdapat pengguna jasa terkait kondisi barang, sedangkan dikemukaan oleh 3 orang karyawan $(27,27 \%)$ kadangkang melakukan komunikasi. Dan 1 orang karyawan yang menyatakan tidak melakukan komunikasi dengan pengguna jasa terkait dengn kondisi barang.

5. Proses Administrasi dalam gudang tergolong mudah/cepat.

Hasil penelitian tentang disampaikan tersaji pada Tabel 4.15 dibawah ini.

\begin{tabular}{|l|r|r|}
\hline Jawaban & Jumlah & \multicolumn{1}{l|}{} \\
\hline Ya & 7 & 63,64 \\
\hline Kadang-kadang & 4 & 36,36 \\
\hline Tidak & 0 & 0,00 \\
\hline Jumlah & 11 & 100 \\
\hline
\end{tabular}

simpulkan secara umumsebanyak 7 orang karyawan $(63,645 \%)$ menyatakan bahwa proses administrasi dalam gudang tergolong mudah dan cepat, sedangkan 4 orang karyawan $(36,36 \%)$ menyatakan kadangkadang proses cepat dan tidak ada yang menyatakan bahwa administrasinya lambat dan tidak tepat.

6. Kerusakan barang diatas batas toleransi.

Tersaji pada Tabel 4.16 di bawah ini.

\begin{tabular}{|l|r|r|}
\hline Jawaban & Jumlah & \multicolumn{1}{l|}{$\boldsymbol{l}$} \\
\hline Ya & 0 & 0,00 \\
\hline Kadang-kadang & 0 & 0,00 \\
\hline Tidak & 11 & 100 \\
\hline Jumlah & 11 & 100 \\
\hline
\end{tabular}

Pada Tabel 4.16 Tidak ada karyawan yang pernah melakukan kerusakan barang diatas batas toleransi. Hal ini ditunjukkan dengan (100\%) pekerjaan dilaksanakan dengan baik tanpa merugikan pihak pengguna jasa.

7. Penambahan pengetahuan guna meningkatkan kinerja.

Dapat dilihat pada Tabel 4.17 dibawah ini.

\begin{tabular}{|l|r|r|}
\hline Jawaban & Jumlah & \multicolumn{1}{l|}{} \\
\hline Ya & 6 & 54,55 \\
\hline Kadang-kadang & 3 & 27,27 \\
\hline Tidak & 2 & 18,18 \\
\hline Jumlah & 11 & 100 \\
\hline
\end{tabular}

Berdasarkan Tabel 4.17, Dapat diketahui bahwa 6 orang karyawan (54,55\%) menyatakan bahwa menambah pengetahuan guna meningkatkan kinerja dan kadangkadang sebanyak 3 orang karyawan $(27,27 \%)$ tidak melakukan penambahan pengetahuan guna meningkatkan kinerja 2 orang karyawaan $(18,18 \%)$. Sehingga dapat disimpulkan bahwa sudah lebih dari sebagian karyawan telah melakukan peningkatan pekerjaan dengan cara mencari pengetahuan yang lebih baik untuk kemampuan menjalankan pekerjaan.

8. Pelaksanaan Tugas secara maksimal.

Hasil penelitian tentang pelaksanaan tugas secara maksimal dapat dilihat dari tabel 4.18 dibawah ini.

\begin{tabular}{|l|r|r|}
\hline Jawaban & Jumlah & \multicolumn{1}{l|}{} \\
\hline Ya & 10 & 90,91 \\
\hline Kadang-kadang & 1 & 9.09 \\
\hline Tidak & 0 & 0,00 \\
\hline Jumlah & 11 & 100 \\
\hline
\end{tabular}

Berdasarkan Tabel 4.18, maka dapat disimpulkan bahwa dalam pelaksanaan tugas secara maksimal dilaksanakan oleh semua karyawan yang ditunjukkan dengan yang menjawab ya sebanyak 10 orang karyawan $(90,91 \%)$ dan yang menjawab kadang-kadang sebanyak 1 orang karyawan $(9,09 \%)$ dan yang menjawab tidak sama sekali tidak ada. 
9. Persentase kerusakan selalu menurun setiap hari.

Persentase kerusakan selalu menurun setiap hari dapat dilihatdan tersaji pada Tabel 4.19 dibawah ini.

\begin{tabular}{|l|r|r|}
\hline Jawaban & Jumlah & \multicolumn{1}{l|}{} \\
\hline Ya & 10 & 90.91 \\
\hline Kadang-kadang & 1 & 9.09 \\
\hline Tidak & 0 & 0,00 \\
\hline Jumlah & 11 & 100 \\
\hline
\end{tabular}

Pada Tabel 4.19 diperoleh 10 orang karyawan $(90,91 \%)$ menyatakan bahwa persentase kerusakan selalu menurun setiap harinya. Hal ini dapat menjadi gambaran bahwa perbaikan-perbaikan kerja dalam pelaksanaan bongkarmuat selalu diupayakan secara maksimal sehingga kerusakan-kerusakan barang bisa menurun setiap harinya. Hal ini menunjukkan bahwa dalam proses operasional bongkar muat ini memang diupayakan sedemikian rupa sehingga kegiatan ini benar-benar berjalan secara optimal.

Tabel 4.21. Tabel Penolong untuk Menghitung Koefisien Korelasi Product Moment

\begin{tabular}{|c|r|r|r|r|r|}
\hline No & \multicolumn{1}{|c|}{ X } & \multicolumn{1}{c|}{$\mathrm{Y}^{\prime}$} & \multicolumn{1}{c|}{$\mathrm{X}^{2}$} & \multicolumn{1}{c|}{$\mathrm{Y}^{\mathbf{2}}$} & \multicolumn{1}{c|}{$\mathrm{XY}$} \\
\hline 1 & 26 & 26 & 676 & 676 & 676 \\
\hline 2 & 28 & 29 & 784 & 841 & 812 \\
\hline 3 & 26 & 27 & 676 & 729 & 702 \\
\hline 4 & 26 & 27 & 676 & 729 & 702 \\
\hline 5 & 27 & 25 & 729 & 625 & 675 \\
\hline 6 & 22 & 23 & 484 & 529 & 506 \\
\hline 7 & 24 & 24 & 576 & 576 & 576 \\
\hline 8 & 27 & 29 & 729 & 841 & 783 \\
\hline 9 & 25 & 25 & 625 & 625 & 625 \\
\hline 10 & 25 & 26 & 625 & 676 & 650 \\
\hline 11 & 24 & 24 & 576 & 576 & 576 \\
\hline Jumlah & 280 & 285 & 7156 & 7423 & 7283 \\
\hline
\end{tabular}

Ket:

$\mathrm{X}=$ Skor operasional Terminal Peti Kemas

$\mathrm{Y}=$ Skor kelancaran bongkar muat

$\mathrm{n}=11$

$\sum \mathrm{X}=280$

$\sum \mathrm{Y}=285$
10. Memahami cara mengheadling dengan benar.

Memahami cara mengheadling dengan benar pada Tabel 4.20 dibawah ini.

\begin{tabular}{|l|r|r|}
\hline Jawaban & Jumlah & \multicolumn{1}{l|}{$\%$} \\
\hline Ya & 11 & 100,00 \\
\hline Kadang-kadang & 0 & 0,00 \\
\hline Tidak & 0 & 0,00 \\
\hline Jumlah & 11 & 100 \\
\hline
\end{tabular}

Berdasarkan Tabel 4.20 di atas, maka dapat disimpulkan bawah Karyawan memahami dan mengerti tentang cara mengheadling dengan benar adalah 11 (100\%) semua karyawan memahami posisi dan kerja mereka masing-masing secara tepat.

Berdasarkan data-data yang diperoleh dari tabel-tabel diatas, maka untuk lebih mudah mencari koefisien korelasi product moment bisa dilihat dalam tabel sebagai berikut: 


$$
\begin{aligned}
r_{x y} & =\frac{n \cdot\left(\sum X Y\right)-\left(\sum X\right) \cdot\left(\sum Y\right)}{\sqrt{\left\{n \cdot \sum X^{2}-\left(\sum X\right)^{2}\right\} \cdot\left\{n \cdot \sum Y^{2}-\left(\sum Y\right)^{2}\right\}}} \\
r & = \\
\frac{11 \cdot(7283)-(280) \cdot(285)}{\sqrt{\left(11 \cdot(7156)-(280)^{2}\right) \cdot\left(11 \cdot(7423)-(285)^{2}\right)}} & \\
r & =\frac{80113-79800}{\sqrt{(78716-78400) \cdot(81653-81225)}} \\
r & =\frac{313}{\sqrt{(316) \cdot(428)}} \\
r & =\frac{313}{367,76} \\
\boldsymbol{r} & =\mathbf{0}, \mathbf{8 5 1}
\end{aligned}
$$

Berdasarkan perhitungan diatas, diketahui $r_{\text {hitung }}=0,851$, dan $r$ tabel $=0.602$, maka terdapat hubungan antara opersional Terminal Peti Kemas dengan kelancaran bongkar muat yang sangat kuat. Hal ini sejalan dengan pendapat Sugiyono (2011:184) bahwa koefisien korelasi tersebut berada pada interval koefisien 0,8 1,0 dan termasuk tingkat hubungan yang sangat kuat.

Selanjutnya untuk melihat besarnya pengaruh diperoleh dari besarnya Koofisien penentu (Kp). Kp - 0,8512 x 100\%, dengan demikan besarnya Kp adalah 72,4\%, hal ini berarti $72,4 \%$ operasional Terminal Peti Kemas sangat berpengaruh kepada kelancaran bongkar muat, sisanya sebesar $27,6 \%$, ditentukan oleh faktor lain.

\section{Uji Hipotesis}

Selanjutnya untuk menguji hipotesis dilanjutkan dengan uji $\mathrm{t}$. Hasil uji $\mathrm{t}$ adalah sebagai berikut:

$$
\begin{array}{r}
t=\frac{r \cdot \sqrt{n-2}}{\sqrt{1-r^{2}}} \\
t=\frac{0,851 \cdot \sqrt{11-2}}{\sqrt{1-0,851^{2}}}
\end{array}
$$

$$
\begin{aligned}
& t=\frac{0,851 \cdot \sqrt{9}}{\sqrt{1-0,724}} \\
& t=\frac{0,851 \times 3}{\sqrt{0,276}} \\
& t=\frac{2,553}{0,525} \\
& t=4,863
\end{aligned}
$$

Hipotesis yang diajukan adalah,

$\mathrm{H}_{0}$ : Tidak ada pengaruh operasional peti kemas dengan kelancaran bongkar muat $\mathrm{H}_{1}$ : Ada pengaruh operasional peti kemas dengan kelancaran bongkar muat

Kriteria pengujian hipotesisnya adalah:

1. Jika thitung $\geq t_{\text {tabel }}(\alpha 0,05 \mathrm{dk}=\mathrm{n}-2)$, maka $\mathrm{H}_{0}$ ditolak dan $\mathrm{H}_{1}$ diterima.

2. Jika thitung $<t_{\text {tabel }}(\alpha 0,05 \mathrm{dk}=\mathrm{n}$ 2), maka $\mathrm{H}_{0}$ diterima dan $\mathrm{H}_{1}$ ditolak.

Berdasarkan hasil perhitungan diperoleh $t_{\text {hitung }}=4,863$, sedangkan $t_{\text {tabel }}(\alpha 0,05$ $\mathrm{dk}=9)$ adalah 1,83. Karena nilai thitung $(4,863)>t_{\text {tabel }}(1.83)$, maka $\mathrm{H}_{0}$ ditolak, dan $\mathrm{H}_{1}$ diterima.

Dengan demikian dapat disimpulkan ada pengaruh operasional Peti kemas dengan kelancaran bongkar muat .

\section{KESIMPULAN DAN SARAN}

\section{Kesimpulan}

Berdasarkan hasil analisis dan pembahasan, maka kesimpulan pada penelitian ini adalah Operasional Terminal Peti Kemas menunjang dalam kelancaran bongkar muat pada PT. Pelabuhan Indonesia II Cabang Panjang. Hal ini berdasarkan hasil analisis statistik yang menunjukkan thitung $(4,863)$ $>$ t tabel (1,833). Besarnya analisis operasional Terminal Peti Kemas adalah sebesar 72,4\% . Hal ini menggambarkan bahwa Operasional Peti kemas merupakan salah satu faktor yang sangat menunjang kelancaran bongkar muat. 
Berdasarkan besarnya koefisien korelasi ( $\mathrm{r}$ $=0,851)$, maka dapat disimpulkan hubungan operasional Terminal Peti Kemas sangat menunjang kelancaran bongkar muat adalah sangat kuat, karena nilai ini koefisien korelasi tersebut berada pada interval koefisien $0,8-1,0$ dan termasuk tingkat hubungan yang sangat kuat. Sedangkan koefisien korelasi yang diperoleh adalah positif $(r=0,851)$, artinya analisis operasional Terminal Peti Kemas sangat menunjang kelancaran bongkar muat, semakin maksimal operasional terminal semakin tinggi menunjang kelancaran bongkar muat.

\section{Saran}

Berdasarkan kesimpulan, maka disarankan pada operasioanl Peti kemas agar dapat meningkatkan kelancaran bongkar muat . Aspek disiplin yang harus ditingkatkan adalah ketepatan waktu proses pembongkaran, membuat persiapan atau fasilitas yang diperlukan.

\section{DAFTAR PUSTAKA}

Aan Komariah dan Djama'an Satori. (2014). Metedologi Penelitian Kualitatif. Bandung: Alfabetha.

Abdul Rachman, Arifin, 2001, Administrasi Pemerintahan dalam Pembangunan, CV. Haji Mas Agung, Jakarta.
A. Furchan. 2004 . Pengantar Penelitian dalam Pendidikan. Yogyakarta: Pustaka Pelajar

Arikunto, S. 2002. Metodologi Penelitian Suatu Pendekatan Proposal. Jakarta: PT. Rineka Cipta.

Arikunto, S. 2006. Metode Penelitian Kualitatif. Jakarta: Bumi Aksara.

Asep, Hermawan. 2005. Penelitian Bisnis Paradigma Kuantitatif. Jakarta: Gramedia Widiasarana Indonesia.

Husein, Umar. 2007. Sistem Perencanaan dan Pengendalian Manajemen.Jakarta: Salemba Empat.

Nazir, Moh. 2005. Metode Penelitian. Jakarta: Ghalia Indonesia.

Siagian P.Sondang. 2005. Organisasi Kepemimpinan dan Perilaku Administrasi. Haji Mas Agung: Jakarta.

Sugiyono, 2005, SratistikaUntukPenelitian, Alfabeta, Bandung.

Sugiyono. 2015. Metode Penelitian Kuantitatif Kualitatif, dan R\&D. Bandung: Alfabeta.

Suyono,R.P. , (2005). Shipping: Pengangkutan Intermodal Ekspor Impor Melalui Laut, Penerbit PPM.

Prihartanto, Wahyu Agung. 2014. Operasi Terminal Pelabuhan. Surabaya: Pelabuhan Indonesia III. 